gap left by Lysenkoism.

Partly as a result of Lysenkoism, Soviet " applied" genetics has a strong commitment to radiation-produced mutations. However, several groups throughout the USSR are known to be working on applied genetic engineering, and there have been several hints that the industrial breakthrough point for "certain medical products" made in this way will be reached "in the nearest future".

Most socialist countries, however, are somewhat secretive as to detail. One exception is Hungary, with its international biology centre at Szeged (built largely by UNDP funds). Work at Szeged, however, is still largely at the stage of establishing techniques and principles. One team, researching on nitrogen fixation, recently started work on establishing a genetic map for Rhizobium and studying the genetic structure of chemically produced mutants.

In Poland, however, the Institute of Biochemistry and Biophysics of the Academy of Sciences would put the breakthrough point for nitrogen fixation by "agricultural plants" at the order of 20 years ahead. According to interviews which specialists from the institute recently gave the prestigious weekly Polityka, they would put on the same time-scale the modification of cereal genes so that the grain proteins would provide the whole range of aminoacids needed for human nutrition. In the "near future", on the other hand, they expect the commercial production of hormones (unspecified), vaccines and special microorganisms designed to clean up pollution. Vera Rich

\section{Germany leads in Europe}

A major initiative in the European Economic community is discussed opposite - but, in outline, Europe starts well behind Japan and the US in the application of modern biology. Within Europe, West Germany is generally reckoned to be in the lead: government spending on the basic problems of biotechnology is about ten times that in France or the UK, for example. Altogether, between 1972-78, the federal government invested $£ 35$ million in biotechnological R\&D.

One of the highlights of the German effort is the Gesellschaft für Biotechnologische für Forschung $\mathrm{mbH}$ at
Braunschweig near Hannover, with an annual budget in 1977 of some $\mathfrak{£ 5}$ million. It was created in the early days of biotechnology - the mid sixties - by the Volkswagen foundation, but was later taken over by government. It has a staff of some 80 researchers and support staff, but has been criticised by some for being insufficiently productive. A new director, Professor Kieslich, has recently been appointed.

The science ministry (Bundesministerium für Forschung und Technology) also plays an active part in funding and planning biotechnological research and development in university and industry; its programme is the envy of biotechnologists in other European countries. So far Germany's greatest efforts lie in its government based research programme.

Italy has a fairly advanced programme, particularly through the activities of the firm SNAM-Progetti, which operates a large laboratory devoted to biotechnology at Monterotondo, near Rome; and Sweden can boast ground-breaking work at the Universities of Lund and Upsalla. In Switzerland Nestlé "is devoting a big effort" (Thomas). (UK and French programmes discussed opposite).

\title{
The origins of biotechnology
}

THE most ancient biotechnological art is fermentation - in the raising of dough, the brewing of alcohol, and the production of tea, coffee, and cocoa (each of which requires a fermentation step). But the new wave of biotechnology rests on two main techniques: genetic manipulation and enzyme (or cell and cell organelle) immobilisation.

Genetic manipulation is used by the biotechnologist to enhance the natural genetic repertoire of a microorganism. The aim is usually to donate to the microorganism a gene for an enzyme or a hormone in such a way that the product of that gene is thenceforth synethesised by the microorganism. The successful development of genetic manipulation has rested upon the discovery of new enzymes and the improvement of old techniques by molecular biologists and microbiologists.

Crucial to the success has been the development of vectors for carrying foreign genes into microorganisms. Also of great importance has been the acceleration of DNA sequencing technology.

The real cornerstone of genetic manipulation, however, has been the discovery of enzymes that cut DNA at specific sites (restriction enzymes), seal the cuts up (ligase) and copy DNA from messenger RNA (reverse transcriptase). The first two of these are needed for the insertion of foreign genes into the DNA of the vector. Reverse transcriptase has become particularly important in the last two years since the revelation that the genes of higher organisms are 'split' (the coding DNA being interrupted by non-coding segments). In sharp contrast, bacteria do not have split genes and cannot decode split genes that are transferred to them. Therefore it is necessary to transfer an unsplit equivalent of the gene, which is precisely what reverse transcriptase produces from messenger RNA. Alternatively, due to recent advances in the technique of DNA synthesis, it is also possible to make purely synthetic genes at least for small peptide hormones.

The use of enzymes is an older technique, applied in a number of industries from baking to detergents. But purified enzymes are soluble molecules and it is therefore not easy to separate them from the product of their labour. Furthermore it is difficult to recycle the enzyme. These difficulties have led to the development, in the late $1960 \mathrm{~s}$, of immobilised enzymes. The enzyme is bound chemically to a solid matrix or entrapped in a smallpore gel.

Immobilised enzymes have been successfully applied, for example, to the production of semi-synthetic penicillins, to the large-scale production of fructose from maize, and to a simple assay for blood cholesterol.

Immobilised cells or organelles have potential advantages when the stabilisation of an enzyme is difficult, or when a coenzyme or sequence of enzymes is required for synthesis.

Biotechnology may be dominated by microbial and enzyme technology, but it is certainly not synonymous with them. Both animal and plant cells have their place in the armoury of the catholic biotechnologist. Successful exploitation of animal cells has been achieved, for example, by Wellcome Research Laboratories in the production of interferon from virusstimulated lymphoblastiod cells.

A completely distinct exploitation of animal cells lies behind the commercial production of high grade antibodies for research, diagnostic and clinical use (for example for tissue typing prior to transplantation). The key to that is the hybridoma cell, an 'invention' of five years ago. Natural antibody-secreting cells neither survive long enough in culture nor produce pure enough antibodies to be a commercial source of antibody. But a hybridoma cell, the result of fusing an antibody-producing cell with a tumour cell, grows and divides continually. And all the cells from the original hybridoma secrete the same, pure antibody.

Work is also going ahead in many countries on the problem of nitrogen fixation - attempting to extend the range of associations of the nodule-forming, nitrogen-fixing, bacterium Rhizobium to plants other than the Leguminosae (particularly cereals), or to transfer the nitrogen fixing genes to plants - a distant prospect, given the extreme oxygen sensitivity of the pathway. There is also the distant prospect, through genetic manipulation, of a new source of controlled genetic variability in plants to produce new high yielding or resistant varieties.

Peter Newmark 